Article

\title{
Group and Child-Family Migration from Central America to the United States: Forced Child-Family Separation, Reunification, and Pseudo Adoption in the Era of Globalization
}

\author{
Carmen Monico $^{1, *(1)}$ and Jovani Mendez-Sandoval ${ }^{2}$ \\ 1 Elon College, the College of Arts and Sciences, Human Service Studies, Elon University, Elon, NC 27244, USA \\ 2 Martha and Spencer Love School of Business, Economic Consulting, Elon University, Elon, NC 27244, USA; \\ jmendezsandoval@elon.edu \\ * Correspondence: cmonico@elon.edu; Tel.: +1-336-278-6485
}

Received: 8 October 2019; Accepted: 27 November 2019; Published: 4 December 2019

\begin{abstract}
Intercountry adoption from Latin America became a sizable, "quiet" migration to the U.S., as evident in its historical evolution from El Salvador, Guatemala, and Honduras. The recent migration of unaccompanied minors and families traveling with children from these case countries has been characterized by child-family separation, prolonged detention and institutionalization of children, and adoption through various means. This study has been concerned with how both trends became intertwined in the era of globalisation. To address this question, the authors examined intercountry adoption literature and migration-related briefs, legal claims, and news reports. The study suggests that internationally recognized child rights have been violated in the border crisis. Forced family separation resulting from stricter immigration measures has met criteria for child abduction, violating international convention protecting families in transnational kinship and adoption. A child-family separation typology was inferred from individual case studies ranging from separation by death to prolonged or indefinitive separation to de facto adoption. Reunification has failed for migrant children in custody since relatives or kinship members may be undocumented or parents may be deported. The current immigration system for migrant children's care only prolongs their detention and violates their human and civil rights while turning child abduction into de facto adoption.
\end{abstract}

Keywords: transnational adoption; global migration; reunification and reunion; child abduction; illegal adoption; migrant children

\section{Background}

The United States is the largest "recipient" country of children declared orphans in countries around the world, but its record concerning child rights is questionable. The relevant international protection system is composed of the Convention of the Rights of the Child (CRC) (United Nations 1989), the Universal Declaration of Human Rights (UDR) (United Nations 1948), and the Hague Convention on the Protection of Children and Cooperation in Respect of Intercountry Adoption (HCIA) (HCCH 1993a). Both the UDR and the CRC defined a set of rights for all people, particularly children (Reichert 2003), and influenced the establishment of international agreements on intercountry adoption. The UDR adopted in post-World War II upheld the right to form a family and the need to protect motherhood and childhood as the right to seek asylum in a second country (Monico et al. 2019a).

Intercountry adoption practice is the movement of children in need of families outside the borders of "sending" countries. Although intercountry adoption has been occurring since WWII, only within the last two decades has it been defined and regulated systematically around the world through the 
HCIA (O'Halloran 2006). In response to the growing practices of child abduction, sale, and trafficking for the purposes of intercountry adoption since the Vietnam War, the HCIA aimed to bridge differences between legal systems across borders (HCCH 1993b, 2008). It was enacted to address a global market of children that included, in some cases, child trafficking and child laundering for the purposes of intercountry adoption (Smolin 2005, 2006, 2010).

Country signatories of the HCIA are expected to uphold the "best interest of the child" in making decisions regarding intercountry adoptions along with the "principle of subsidiarity," which gives preference to family and kinship placement and to national adoption before considering intercountry adoption (HCCH 1993a, 2008). Complementary to the HCIA is the Guidelines for the Alternative Care of Children, which not only upholds the principle of subsidiarity but also calls countries to avoid family separation. These guidelines were issued to protect children in emergencies by encouraging countries to keep families intact and to avoid alternative care placements, particularly outside their borders, "except temporarily for compelling health, medical, or safety reasons" (United Nations 2010, p. 22). Although the U.S. promoted the UDR and endorsed HCIA, the country has signed the CRC but it has not yet ratified it. As discussed later, the treatment of child migrants from Central America at the border while in detention or in institutional care and once released from custody has been problematic. This is because the U.S. does not abide by international conventions; in fact, it violates its own minimum child protection laws that were developed over 50 years.

Globally, intercountry adoption in the new millennium has been characterized as a "quiet migration" in which children declared orphans and adoptable in their country of origin are welcomed in another country by families facing infertility or because of the limited availability of children for domestic adoption (Weil 1984; Selman 2002). Intercountry adoptions are traced back to the mid-1940s when large numbers of orphan children became available for adoption in post-World War II, with approximately one million children adopted internationally since then (Selman 2012). Because the U.S. became the largest recipient worldwide, studying this country provides a good representation of global trends.

The U.S. became a signatory of the HCIA in 1994, ratified it in December 2007 (HCCH 2011), and enacted the Intercountry Adoption Act in 2000, which went into effect in April 2008. While countries around the world started to adopt stringent child protection regulations, a significant reduction in intercountry adoption followed starting in 2004 (Selman 2006, 2009). A little under 23,000 adoptions per year was the highest number reported with significant reductions of approximately $60 \%$ observed in 2004 (U.S. Department of State 2019). Thus, the total intercountry adoptions to the U.S. have dropped substantially in the past decade, from 22,726 in 2005 to 4058 in 2018 (U.S. Department of State 2019).

Alstein and Simon (1991) identified five distinct phases in the evolution of intercountry adoption (ICA) coinciding with key world and regional events: (1) post-War World II, (2) the end of the Korean and Vietnam Wars, (3) the civil wars and economic instability in Latin America, (4) the end of the Cold War, and (5) China's one-child-per-family policy. Based on an extensive literature review, the Monico (2013) identified three additional phases: (6) rapid globalization of ICA, (7) the era of major ICA reforms, and (8) loopholes in ICA standards. A review of 35 years of the literature on intercountry adoption on this historical evolution is summarized in Rotabi et al. (2015). In this article, the author draws from the phases related to Central American northern triangle countries (phase \#3), to the massive movement of people across borders in search of protection during times of globalization (phase \#6), and the implementation of the HCIA with its reforms (phase \#7) and loopholes (phase \#8).

Globally, refugee rights were adopted after World War II through the Convention on the Treatment of Refugees; later, the Protocol to the Refugee Convention strengthened protections to those seeking refuge worldwide (United Nations High Commissioner for Refugees 2010). After the U.S. ratified this protocol, it enacted the Refugee Act of 1980 (Public Law 96-212 1980), which affirmed the right that all foreigners ("aliens") have to apply to political asylum within its borders. If applicants do not meet the asylum criteria, "safe third countries" are considered; that is, in cases "in which the alien's life or freedom would be threatened on account of race, religion, nationality, membership in a particular 
social group, or political opinion and where the alien would have access to a full and fair procedure for determining a claim to asylum or equivalent temporary protection" (8 U.S. Code $\$ 1158$ Asylum 2008, p. 1). Other protections applicable to migrant children and their families are contained in the United Nations Convention against Transnational Organized Crime and the Protocols Thereto, specifically, the Protocol against the Smuggling of Migrants by Land, Sea, and Air and the Protocol to Prevent, Suppress, and Punish Trafficking in Persons, especially Women and Children, (United Nations 2000). In the U.S., protections for migrants who become victims of human trafficking are considered in the Trafficking Victims Protection Act (TVPA) of 2000, as explained next. Poverty, another form of human right violation, has fueled intercountry adoption (Smolin 2007).

The TVPA of 2000 established that human trafficking and related cases are a federal U.S. crime tried with severe penalties. The Act mandated the trafficking-in-persons (TIP) reports each year, which describe and rank the efforts of countries in combating human trafficking. The Trafficking Victims Protection Reauthorization Act (TVPRA) 2003 reauthorization allowed the trafficking victims to sue their traffickers and created additional protections for victims and families from deportation. The 2005 reauthorization launched a pilot program to shelter minor survivors of human trafficking, expanded the powers of state and local law enforcement fighting human trafficking, and sought to combat human trafficking at the international level. The 2008 reauthorization stipulated prevention strategies, such as providing information regarding workers' rights to applicants of work and education-related visas, and required that all unaccompanied minors entering the U.S. be screened for human trafficking. Passed as a Violence Against Women Act (VAWA) amendment, the 2013 reauthorization fund programs ensured that U.S. citizens do not buy products made from victims of human trafficking and prevented child marriage. This last reauthorization helped strengthen the cooperation between the state and local law enforcement, therefore making it more efficient in prosecuting human traffickers (Polaris n.d.).

Because migrant children from Central American northern triangle countries continue to "experience lack of protection and mistreatment while navigating various stages of the U.S. immigration system, including apprehension, screening, custody, and adjudication" (Ataiants et al. 2018, p. 4), they should continue to benefit not only from protections considered in the Flores Settlement Agreement but also from those built in the TVPRA. They should also be given fair access to legal representation and due diligence with their asylum claims and cases. The existing legal protections must be strengthened, not weakened. On 2 August 2019, a Maryland District judge blocked “the government's implementation of a policy that would significantly limit vital protections for children under the Trafficking Victims Protection Reauthorization Act (TVPRA)" (Catholic Legal Immigration Network et al. 2019, p. 1). The TVPRA would protect the rights of thousands of unaccompanied immigrant children seeking asylum. It would protect those who were separated from their parents and are facing deportation, inadoptability in the foster care system, or de facto adoption.

The Catholic Legal Immigration Network article provides a historical review of intercountry adoption and child protection in Central America and a summary of the evolution of child and family migration from the 3 countries of the region's northern triangle. It offers an analysis of the evidence from 13 case studies regarding the treatment of those immigrant children in the U.S. under the administration of President Donald Trump. The article identifies patterns in policy options and administrative hurdles in the system of care of immigrant children in U.S. territories. It discusses the implications for the protection, development, and well-being of child migrants. Finally, it identifies key lessons learned for transnational adoption and kinship in this era of globalization in which child migration has substantially increased.

\section{Materials and Methods}

The selection of the case studies was conducted based on the relevance of the cases to the purpose of the research. The 3 country case studies presented in this article were selected because the majority of unaccompanied minors and families traveling with children during the human rights crisis at the border has been from Honduras, El Salvador, and Guatemala. The 13 individual cases were selected 
based on the preponderance of information available and the significance of the cases to establish precedent in immigrant policies and practices. The individual cases were classified into 4 categories constructed by the authors based on the evidence regarding each case.

The first author summarized the intercountry adoption literature using data from her doctoral dissertation study and from research conducted on the current humanitarian and human rights crises emerging from the large influx of unaccompanied minors and families with small children at the U.S. southwestern border. To develop the country and case studies, both authors examined official international reports from a wide range of international organizations and government agencies, legal documents, and media reports from multiple journalists covering immigration news.

The research presented here did not involve human subjects. All data sources are of public domain and found in academic books or journals, in official reports or reports from nonprofit organizations, and news investigative articles. For replication purposes, the authors have included all references related to these case studies.

\section{Historical Evolution of Intercountry Adoption from Latin America and Child Protection in Central American Northern Triangle Countries: Country Case Studies}

Intercountry adoptions from Latin America to the United States increased three-fold from 1973 to 1975; that region accounted for 17\% of all intercountry adoptions to the United States in 1975 and 23\% in 1987 (Alstein and Simon 1991). From 1976 to 1981, Ecuador and Colombia were among the top major countries "sending" orphaned and vulnerable children to the United States (Selman 2006). Adoptions from Latin America in 1973 represented only 8\% of international adoptions to the United States, but they increased to 32\% in 1993 (Hollingsworth 2003). Intercountry adoptions from Latin America have declined significantly since the early 1990s, representing only $10 \%$ of U.S. intercountry adoptions in 1997; in fact, the contribution from that region has been substantial over time (Hollingsworth 2003).

Immigration from Latin American countries has declined in part due to the adoption of regulations that are more aligned with the HCIA, which has been a global trend also observed since 2014 (Rotabi et al. 2015). The enactment of more protective laws often results in lengthier times of intercountry adoption and fewer loopholes for engaging in illegal adoptions for profit-making (Rotabi et al. 2015). In fiscal year 2018, the U.S. reported a total of only 20 "orphan" children from the following subregions: Guatemala (1), Honduras (14), and El Salvador (5) (U.S. Department of State 2018). These countries provide useful examples of country experiences taking place during and after the civil wars in the Central American region. Furthermore, they are directly relevant to this article, given the history of child abduction in similar cultural and geopolitical contexts.

The armed conflicts and natural disasters in El Salvador and Guatemala promoted the historical rise in intercountry adoptions from Latin America (Bromfield and Rotabi 2012; Bunkers et al. 2009; Rotabi 2007; Rotabi et al. 2008; Selman 2012). The limited legal and social protections for mothers and families in those countries appeared to have contributed to the neglect or abandonment of their children (Goldschmidt 1986) and to the preference of international adoption as a "quick solution" (Roby et al. 2013). Scholars found evidence that children in that region were "placed for adoption after having been purchased, indentured, or abducted" (Herrmann and Kasper 1992, p. 51). In these cases, it is problematic to use the term "birth parents" when there has not been a legitimate (non-fraudulent) adoption legal determination. For that reason, the term "biological parents" has been used in this article to refer to what has been ordinarily referred to as birth parents in the adoption literature.

Violence against women as a social context for child abduction became an important element in the evolution of Guatemalan adoptions (Bunkers and Groza 2012). Guatemala is the country where most children and their families are leaving to seek refuge in the U.S. and where femicide, the killing of women, has been widespread (Sanford 2008). Honduras and El Salvador have been categorized as some of the most dangerous places in the world. In fact, Central American northern triangle nations have a high rate of organized crime due to poor law enforcement and institutional organization. Gangs use violence to control the flow of drugs in and out of the country and to establish their dominance 
in the region. The decades of drug policy in the region have contributed to the "balloon effect" that created the mass migration observed in these years (Gendle and Monico 2017).

Persistent and weak child protection in the region promoted the violation of children's rights, specifically forced separation, child abandonment, and adoption (Instituto Latinoamericano para la Educación y la Comunicación, ILPEC 2000) as the main welfare practices. Intercountry adoptions from Honduras have not been subjected to extensive scholarly investigation. However, that country has suffered armed conflicts and natural disasters. The three countries have endured gang violence and endemic poverty in the past two decades, which are factors identified as major driving forces of the massive influx of migrant children and their families (United Nations High Commissioner for Refugees 2014). These countries are analysed as case studies after examining global and subregional trends.

Figure 1 below depicts statistics on adoptions from fiscal year (FY) 1999 through FY2017 (U.S. Department of State 2019) using a logarithm of base 10 to compensate for the large difference of incomparable data. The total intercountry adoptions to the United States is 275,891 , with those from Guatemala being 29,808, from Honduras being 241, and from El Salvador being 179. Even when historically the three countries were engaged in illegal adoptions, the largest commercialization of children for intercountry adoption happened in Guatemala. This latter country became a top sending country (of children declared orphans or adoptable) before enacting a new adoption law in 2017. Adoptions from these countries are minimal when compared to the total number of adoptions during the same period.

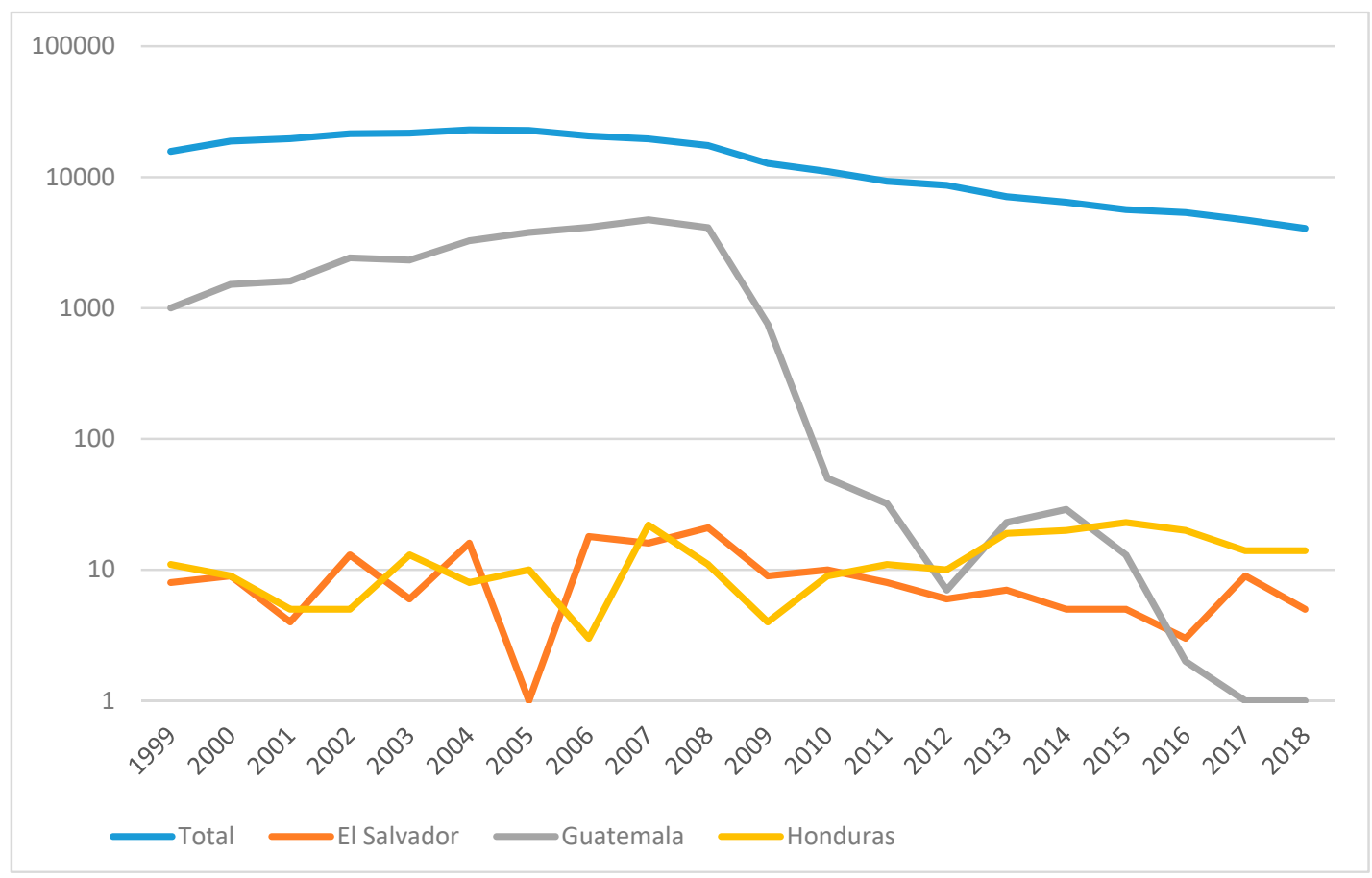

Figure 1. Intercountry adoptions to the United States from all countries vs. Central American northern triangle countries (U.S. Department of State 2019).

\subsection{The Case of El Salvador}

The 20-year civil war (1970-1990) in El Salvador resulted in the killing of an estimated 75,000 Salvadorans, the internal displacement of a half million people, and the dislocation of a million people who sought refuge in other countries (Monico and Rotabi 2012). The conflict provoked the massive forced separation of and the disappearance of an unknown number of children who were either institutionalized or adopted domestically and internationally in the United States, Italy, France, and Honduras (Monico and Rotabi 2012). Pro-Búsqueda is a nongovernmental organization 
assisting biological families in their search for their forcibly "disappeared" children. This nonprofit has investigated the existence of illegal intercountry adoption networks that charge $\$ 10,000$ per adoption and falsify documentation throughout the adoption process (Monico and Rotabi 2012). Pro-Búsqueda investigations found over 800 cases that provide evidence of how vulnerable children are in emergency situations, such as during a civil war.

Monico and Rotabi (2012) offer a detailed account of the process of search and reunion that Pro-Búsqueda has undertaken since it was established with the support of biological families of the disappeared children. Each case has been resolved with the collaboration of a large network of national and international collaborators and informants and has resulted in national and international litigation. The investigated cases led to the identification of the disappeared children within and outside El Salvador and facilitated "reunions" of adult adoptees with biological parents and relatives. These highly emotional reencounters have involved the local communities of the biological parents and relatives and, occasionally, the adoptive parents, to whom Pro-Búsqueda also offers psychological support.

Pro-Búsqueda has resolved 443 cases using a seven-stage process. The stages complete the case intake including DNA testing, gathering testimony regarding the moment of disappearance, investigating the context, following leads with those involved in relevant events, following more leads with higher authorities, reporting to the biological relatives on investigation findings, and providing psychological support to everyone involved throughout the process (Monico and Rotabi 2012). El Salvador has strengthened its regulatory framework to protect children and youth and has placed this population at the center of its national development plan. However, this country has "one of the highest murder rates of children in the world: At least one child per day continued to be murdered" (United Nations Human Rights Office of the High Commissioner 2018a, p. 1).

\subsection{The Case of Guatemala}

The 36-year civil war (1960-1996) in Guatemala produced an estimated 100,000 to 200,000 killings and disappearances, particularly among Mayan people (many of them women) who were mostly victims of the military and paramilitary forces; in addition, 1.5 million people were displaced (REMHI 1999; Sanford 2003, 2008). After the war, the United Nations-sponsored Commission for the Historic Clarification documented 410 massacres of civilians; thousands of cases involved forceful disappearances; kidnappings; rape as a war weapon; and other forms of torture, illegal detentions, and personal and institutional attacks (REMHI 1999; Sanford 2008). The 1999 REMHI report points to the implication of the armed forces used in the "forced separation of families, in which children were subjected to re-education in special homes; there were some cases of children who were separated from their families or communities, abducted, and fraudulently adopted by the perpetrators of violence against their families" (p. 38).

Investigations conducted regarding the "disappearance" of children during the war found an undetermined number of child abductions that resulted in international adoptions. Post-conflict adoptions boomed, with over 200 agencies operating in the nation by 2005 (Rotabi 2009). "Baby flights," which was the term used among adoption agencies and families, were constantly departing from Guatemala (Rotabi and Bunkers 2008), as child abductions continued after the signing of the Peace Accords when they increased. The U.N.-sponsored International Commission against Impunity in Guatemala (CICIG 2010) concurred with those findings, characterizing them as gross human rights violations, particularly of those "missing" children who were illegally separated from their families and then adopted illegally. Under the "notarized" system prevailing in Guatemala prior to December 2007, the cost of each intercountry adoption was between $\$ 30,000$ and $\$ 40,000$; in fact, illegal adoptions involved a wide range of actors in organized crime networks linked to government officials (CICIG 2010).

After conducting an extensive review of the history of intercountry adoption and conducting constructivist inquiry with mothers whose children were stolen, trafficked, and sold in intercountry adoption during this period in Guatemala, Monico (2013) confirmed a working definition of child 
abduction to include child theft, deceptive, coercion, and fraud. Child protection laws and child development services have improved in Guatemala since intercountry adoptions were suspended and a new adoption law was enacted. However, "widespread violence in the country, the poverty rate among indigenous children, and continued recruitment of children by criminal gangs (maras)" continue, along with overcrowding and unsafe conditions in child facilities, and the endemic problems with "street children and trafficking of children" through various means of exploitation (United Nations Human Rights Office of the High Commissioner 2018b, p. 1).

\subsection{The Case of Honduras}

Honduras has a long history of corruption and dictatorship, as well as gang violence, civil unrest, and environmental fragility. With nearly half of the population living in poverty, Honduras is the most unequal country in Latin America and is ranked as one of the most deadly countries in the Americas based on the number of homicides; as international corporations continue to exploit its natural resources, the country becomes more susceptible to natural disasters (BBC News 2018; World Bank 2019). Drug trafficking is an ongoing security concern as "U.S. officials report that $90 \%$ of documented cocaine flows into the United States now pass through the region" (Rocio and Renwick 2018, p. 1). The major challenges in this country are police abuse and corruption; attacks on protesters, journalists, lawyers, human rights defenders, and environmental activists; homophobic violence against LBGTQIA+ individuals; criminalization of abortion; prevalence of child marriage; and inhumane conditions in prisons (Human Rights Watch 2018). Although the Mission to Support the Fight against Corruption and Impunity in Honduras (MACCIH) was created in 2016 under the auspices of the Organization of American States (OAS), corruption and money laundering persist.

Intercountry adoptions from Honduras have been found to involve child trafficking. Durran (1993) claims that a "lucrative baby trade netted over two million dollars during the last nine months of 1991. Civil servants, court officials, and over 60 lawyers are implicated in the racket ... [with charges of] $\$ 12,000$ in legal fees per child" (p. 1). Honduras eventually became one of the 20 world countries from which intercountry adoptions significantly decreased or halted (Smolin 2006). Honduras ratified the HCIA on 6 March 2019 and has adopted a national law on adoption aimed at preventing illegal adoptions. However, a U.N. Special Rapporteur report on the sale of children for sexual exploitation and child pornography confirms that child trafficking continues to be a serious problem in Honduras, as there is no evidence of child protection regulations and systems built against these crimes (United Nations 2014).

\section{From Apprehension to Separation to Institutionalization and De Facto Adoption: Individual Case Studies}

\subsection{Forced Child-Family Separation Resulting from U.S. Immigration Policies}

In the past decade, the majority of migrants apprehended at the U.S. border have been from Mexico and the northern triangle countries, with increasing numbers of unaccompanied minors from Honduras, Guatemala, and El Salvador (Gendle and Monico 2017). In these countries, criminal networks are established across borders. The widespread government corruption and impunity impedes the effective arrest, prosecution, and punishment of both traffickers (those who exploit victims during transportation or a destination) and smugglers (those who transport for a profit, other than sexual or labour exploitation), even in countries where smuggling and human trafficking are legal. Unaccompanied minors from the Central American northern triangle countries are exposed to violence in their home countries because of this high prevalence of organized crime. The resulting trauma among immigrants increases with the mistreatment by both smugglers and human traffickers (Estefan et al. 2017).

Families and young women are migrating to the United States because of gangs, poverty, and violence against women. In 2016, more than 70\% of migrants from Central American northern triangle 
countries were estimated to flee their homelands because of violence; in fact, during the same year, 400 femicides (female victims of homicide) were recorded in Honduras alone, with just 15 of those being investigated and only 2 convictions (Filipovic 2019). Structural violence and the patriarchal society in El Salvador force "children and adolescents [to] confront discrimination and [to] experience habitual deprivation of their right to develop.... [They] do not have access to education, skills training, job opportunities, and health care" (Center for Gender and Refugee Studies of the University of California Hastings College and the Migration \& Asylum Program Justice and Human Rights Center of the National University of Lanús 2015, p. v). Other "push factors" of migration of families and children include poverty, gang violence, and the lack of educational opportunity, which encourage families to reunite with relatives in spite of the dangerous migration trip (Estefan et al. 2017). They endure danger when traveling through various migration routes just to face many challenges upon arrival (United Nations Children's Fund (UNICEF) 2016). Children between 0 and 12 years of age make up 17\% of those migrating into the U.S. and are the most vulnerable population for mental and physical health consequences to trauma (Estefan et al. 2017).

The zero-tolerance policy under the Trump administration aimed at deterring the massive migration of mostly Central American children and family units. Its brief implementation during 2018 resulted in reinforcing administrative practices of forced child-family separation. As discussed extensively in Monico et al. (2019a, 2019b), this policy was a response to the increased number of migrant children and their families crossing the U.S. southwestern border. It was also a challenge to the 1997 Flores Settlement Agreement, which prohibited the detention of children for more than 20 days and ordered their placement in child-friendly facilities. Following the zero-tolerance policy, the Customs and Border Protection (CBP), originally entrusted with law enforcement, separated accompanied children from their families, declared them unaccompanied, and put them under the care of the Office of Refugee Resettlement (ORR) for placement into adequate facilities.

The American Civil Liberties Union (ACLU) requested and was granted an expansion of the Ms. L v. U.S. Immigration and Customs Enforcement (ICE) litigation to be used as a guideline for reunifying children with their families by June 2018 (ACLU 2018a, 2018b, 2018c); ICE is responsible for enforcing immigration laws within the U.S. According to ACLU (2018d), [“Of the initial pool of 2654 separated children, the majority was male (64.5\%). 1033 of them were under the age of ten when they were detained, including 103 under five"] "Of the initial pool of 2,654 separated children, the majority was male (64.5 percent). 1,033 of them were under the age of ten when they were detained, including 103 under five" (p. 1). In January 2019, the Office of the Inspector General (OIG) of the U.S. Department of Health and Human Services (2019b) identified 2737 children affected by the zero-tolerance policy as M.L class members eligible for reunification. This report also confirmed that over 118 children had been separated since the court order by November 2018 and that "thousands of children may have been separated during an influx that began in 2017, before the accounting required by the court" (U.S. Department of Health and Human Services 2019b, p. 1). Furthermore, the OIG found that ORR systems and processes are insufficient and that the U.S. Department of Homeland Security (DHS) "provided ORR with limited information about the reasons for these separations, which may [have] impede[d] ORR's ability to determine appropriate placements" (U.S. Department of Health and Human Services 2019b, p. 2).

The lack of effective data records tracking both children and families made it more difficult for the CBP and ORR to interact with these children and their families (Estefan et al. 2017) in their respective roles. In fact, despite international and domestic commitments to non-refoulement, CBP's "expedited procedures place children and adolescents traveling with their biological parents at risk of return to persecution or torture or to situations harmful to their best interests." (Center for Gender and Refugee Studies of the University of California Hastings College and the Migration \& Asylum Program Justice and Human Rights Center of the National University of Lanús 2015, p. xii). This failed system has impeded the effective and timely reunification of those affected by the zero-tolerance policy in spite of several court orders calling government agencies to expedite this process (Monico et al. 2019a, 2019b). 
An indication of the immigration system failure is the gross violations of human and civil rights that migrant children continue to fac, and the implications of harmful immigration policies on the health and overall development and well-being of children (Monico et al. 2019a, 2019b). The same system has prevented an effective understanding of how to deal with trauma exposure and prevention (Estefan et al. 2017). It has created lifetime trauma and emotional stress for both the biological parents and the children, who are often unaware of each other's well-being (Jordan 2018). It has brought controversy with the uncertainty of how the government would reunite families already separated (Spencer and Steve 2018).

The Trump administration has shown a lack of empathy towards migrant children. A cross-sectional study involving 245 children in immigration detention in the U.S. in mid-2018 confirmed that the severely adverse impact of detention is detrimental to their mental health (MacLean et al. 2019). Key study results included that "Children who had been forcibly separated from their mothers demonstrated significantly more emotional problems $(49 \%, p=0.003)$ and total difficulties $(15 \%, p=0.015)$ than those who had never been separated. Of the 150 children who completed the PTSD-RI [UCLA Post-Traumatic Stress Disorder Reaction Index Symptom Scale], 17\% had a probable diagnosis of PTSD [post-traumatic stress disorder]. In all, nearly half (44\%) of all children demonstrated at least one emotional or behavioral concern" (p. 303). The authors confirmed that denial of proper care to these children while in detention, compounded with prior trauma, is detrimental to their health and developmental growth.

A joint investigation of the Associated Press and the Public Broadcasting Service series FRONTLINE concluded that the U.S. has reached a world record in child migrant detentions with close to 70,000 children held in custody in various government-run facilities throughout the U.S. during fiscal year 2019; a 42\% increase with respect to fiscal year 2018 (Sherman et al. 2019). Figure 2 below depicts the increase in the apprehension of unaccompanied alien minors (UACs) and family units in the last few years with those found "inadmissible" or without merit to be admissible to enter the U.S. (U.S. Office of the Federal Registrar 2019). Those found "inadmissible" may be due to health reasons, to having a criminal background, to being considered a threat to nation's security, to likely becoming a public charge, to being found to have committed fraud or misrepresentation, or to having a record of prior removals (deportation) (USCIS n.d., 2019). Although it is possible to request a waiver of inadmissibility, exceptions are possible for immigrants "who have been battered, abused, or subjected to extreme cruelty; who are victims of severe forms of trafficking; and who are minors" (USCIS n.d., p. 2).

Due to the expedited decisions by DHS officers on these cases and to the lack of legal representation at the border, those apprehended are likely found inadmissible and returned to their countries of origin or to another "safe third" country. The U.S. has established agreements with other countries to contain migration at its southern border, which are likely to further erode existing protections for those seeking asylum. In a letter to the Secretary of State and the Acting Secretary of Homeland Security, the chairmen of three committees of the U.S. House of Representatives characterized the U.S. negotiations of Safe Third Country Agreements with Mexico and Guatemala as unlawful (Engel 2019). In Mexico, during the first seven months of fiscal year 2019, 64,000 migrants from the northern triangle countries of Central America were deported to their countries of origin (Gzesh 2019). In Guatemala, about 24,000 migrants, mostly from Honduras, have been in transit during 2018 while less than 300 of them filed for asylum (Gzesh 2019). Both countries are known for their widespread organized crime and human rights violations against persons migrating within and outside of their borders, as well as for the countries' inability to "provide protection or due process to migrants required under law" (Gzesh 2019, p. 1).

On 11 September 2019, a Supreme Court decision lifted a block on a lower court injunction to a new asylum rule introduced by the Trump administration. On 16 July 2019, the Justice Department and DHS adopted the new asylum rule, and the U.S. Court of Appeals for the 9th Circuit issued the injunction soon after, preventing the California and Arizona borders from implementing it; the suspension on the ruling did not apply to the New Mexico and Texas borders. The ruling will be 
implemented while ACLU's claim on behalf of various immigration groups is fully litigated in the district courts and later in the Federal Courts of Appeals in San Francisco, which may take a couple of years. The ruling effectively restricts the right to asylum to seekers from the Central American northern triangle countries and elsewhere at the U.S.-Mexico border. This right is granted under the U.S. Immigration and Nationality Act (INA) to all foreigners reaching the U.S. based on fear of persecution in their countries of origin.

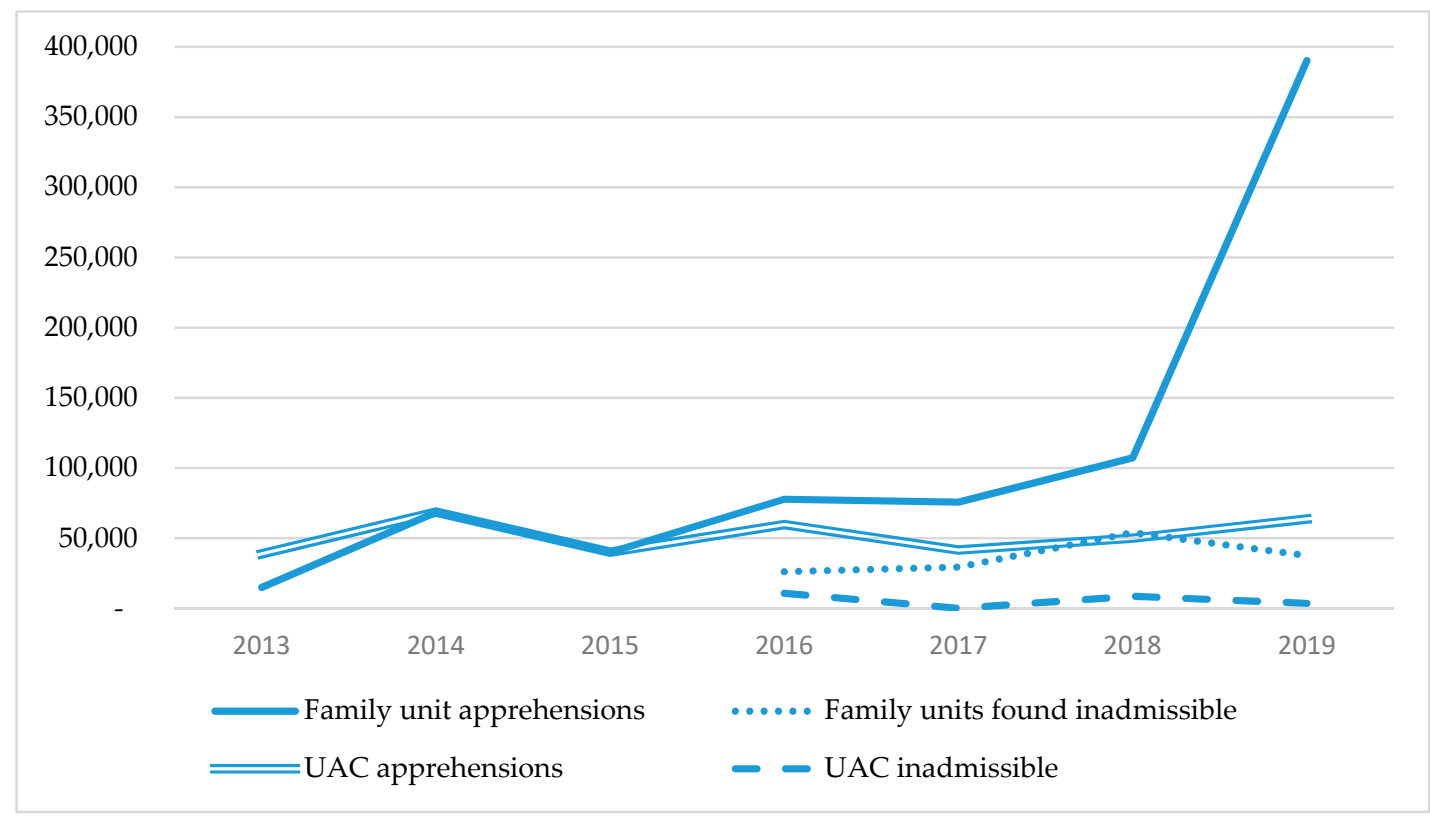

Figure 2. Family unit and unaccompanied alien minor (UAC) apprehensions and inadmissible (U.S. Office of the Federal Registrar 2019).

\subsection{From Apprehension to Separation to Institutionalization and De Facto Adoption: Individual Case Examples}

The various forms of parent-child forced separations have resulted in indefinite or prolonged separation, institutionalization, or de facto adoption. The 13 cases studied were clustered into four categories:

(1) Separation by death: the death of toddlers, young children, youth, and adolescents during or soon after U.S. government custody;

(2) Prolonged separation: the return of children to biological parents and relatives after extended or indefinite separation;

(3) No reunification insight: families divided before, during, and after the zero-tolerance policy, with children remaining institutionalized as they are not eligible for adoption; and

(4) Definite or temporary loss of parental rights: the loss of parental rights after detention of biological parents due to criminal charges (crossing without CBP inspection), the use of fraudulent documentation at work, or cases of domestic violence (those reported and investigated but not necessarily substantiated).

What follows is an examination of some of these cases.

\subsubsection{Cases of Separation by Death}

Regarding separation by death, well-known cases are those of Jakelin Amei Rosmery Caal Maquin (7 years old), who died of bacterial infection presumably contracted while in CBP custody, and of Felipe Gomez Alonzo (8 years old), who died of influenza B arguably after lacking proper care while in CBP custody. The deaths of these children raised awareness that the majority of migrant children entering 
unaccompanied or with their families from Guatemala are from one of the 25 Mayan groups. A Center for American Progress study found that "Unlike the DHS plan which considers the provision of reasonable accommodations for non-English speakers, however, $\mathrm{CBP}^{\prime}$ 's plan specifically contemplates a protocol for law enforcement personnel who encounter individuals with low English proficiency, including children" (Jawetz and Shuchart 2019, p. 1). Because many of them do not speak English, communication becomes a matter of death and life for them (Jordan 2018). Several of those who have died in immigration detention or shortly after release have been of a Mayan group, even if the proportion of people of indigenous origin with respect to the total apprehensions is unknown (Jordan 2018). Although a total of 24 immigrants have died under ICE custody (Rappleye and Riordan Seville 2019), these cases also highlight the vulnerability of migrant children of indigenous origin.

Separation by death has included that of an adolescent who, in April 2019, became the third child, besides toddlers, to die in U.S. immigration custody in the first five months of 2019. The 16-year-old boy from Guatemala was detained by U.S. border patrols and was sent to a government-contracted youth shelter in Texas to start a family-reunification process. The Department of Health and Human Services stated that "upon arrival to the shelter the minor did not note any health concerns" (Ingber 2019, p. 1). The next day, staff members noticed that the minor was complaining about symptoms of "fever, chills, and a headache" (Ingber 2019, p. 1). The minor was taken to a local hospital to receive treatment, but his health did not get better when he returned to the shelter. He was later rushed to a children's hospital. Unfortunately, the young boy died the next day. The cause of his death was because of a "severe infection in the frontal lobe that showed no improvement, even after a surgical intervention to stabilize the pressure inside the head area" (Ingber 2019, p. 1). The biological parents of the minor were not able to secure humanitarian visas because they were too young to obtain one (Ingber 2019).

The last case of separation by death is that of a mother and her 2-year-old-boy from Guatemala who were apprehended when they tried to cross the Texas border in May 2019. Border Protection officials claimed that the mother complained that her son was experiencing "high fever and difficulty breathing" (Burnett and Romo 2019). The child was taken to a local hospital and diagnosed with pneumonia. The boy's condition worsened, and unfortunately, he passed away because of health complications. The child's mother is currently in the U.S. waiting for her legal immigration case (Burnett and Romo 2019). This became the fourth child to die while being detained by Border Patrol since December of 2018 (Merchant 2019). All four minors who died in U.S. government custody were from Guatemala, a nation that is extremely poor and overrun by organized crime organizations. Having four children die in the past six months shows that there is a lack of humane treatment of migrant families (Merchant 2019).

\subsubsection{Cases of Prolonged Separation}

The great majority of unaccompanied minors apprehended at the U.S. border are placed in government shelters, with most facilities reaching 95\% capacity (Jordan 2018). In 2019, a 66-percent increase in UACs was reported with respect to 2018. The facilities are often called "ice boxes" because they are kept very cold and contribute to detainees falling ill. A 16-year-old mother from El Salvador and her 1-year-old baby were separated from the father and placed in a very cold facility. She stated, "we stayed in a room with 45 other children. There was no mat so my baby and I slept directly on the cement" (Chapin 2019, p. 1). Both the child and mother were sick and were not offered a way to shower or to brush their teeth since they arrived at the immigration detention center (Chapin 2019). The overall process from CBP training to facility adjustments must be reevaluated to support the overall health status of detained migrant families and children (Hennessy-Fiske 2019).

Prolonged child-parent separation has been observed in these cases, with traumatic consequences from being separated from their biological parents and from being placed in different environments. For example, a 3-year-old boy from Honduras was separated from his father and the child had a difficult time transitioning into a new foster parent system. Two years later, when the child spoke to his biological parents for the first time since their separation, he realized that his father was still detained, 
his mother was in Honduras, and that there was no possibility of meeting them again. This reignited the trauma and emotional stress of the young child (Jordan 2018). Migrant children have been exposed to long-term traumatic consequences due to physical and sexual violence in U.S. government-funded facilities. According to the Office of Refugee Resettlement, from 2014 to 2018, there have been 4556 complaints of sexual abuse or harassment of unaccompanied minors under investigation (Haag 2019). This included 1303 cases of adult staff members and other minors harassing, assaulting, and even raping migrant children and watching them shower (Haag 2019).

The least expensive option that human smugglers offer migrants is the "bargain-basement deal" when a parent and child turn themselves in to U.S. border officials and file for asylum (Root 2019). Unlike single adults, the parent and child would wait for a court date to review their status. Carlos, a father from Honduras, brought his 6-year-old daughter, Heyli, on an arduous trip to the U.S. They faced mistreatment along the way and took out loans to pay the smugglers for bringing them to the U.S. border. Once there, they turned themselves to CBP officials at the border (Root 2019). Unaware of President Trump's zero-tolerance policy, both Carlos and Heyli were charged with a misdemeanour for crossing the border without inspection. After pleading guilty to that crime, Carlos was sent to a detention center and his daughter was moved to a shelter for migrant children. Carlos was not informed about his daughter's well-being and location. In June 2018, federal judges ordered the Trump administration to reunite separated families within 30 days. It was after two months and after Carlos signed for voluntary deportation that he was reunited with his daughter. Both Carlos and Heyli now live in the U.S. with long-term trauma and fear of being separated, facing financial struggles to pay off the pending debt and facing an uncertain future giving their legal status (Root 2019).

Beata Mariana de Jesus Mejia-Mejia had a similar experience. She left Guatemala because of violence and death threats from her husband, causing her to seek asylum in the U.S. (Spencer and Steve 2018). The Mejia family arrived at the U.S. border and turned themselves in to the border patrol agents. Without an explanation, the 7-year-old boy Darwin Micheal was moved to a different facility while the mother stayed in detention. Mejia was not charged criminally for crossing the U.S. border, but this was a case of family separation deterring asylum-seeking individuals. Although mother and son are together now, it is still unclear if the young boy had experienced mistreatment during his separation from his mother. CBP separated the mother and son from each other and did not provide any updates about her son while in detention. Attorneys claim that this is a tactic used to discourage other migrants from seeking asylum in the U.S. (Spencer and Steve 2018). In a similar case, a father anonymously and his 6-year-old daughter were detained at the U.S. border. They were separated from each other during U.S. custody, and the father was transferred to his third detention center and was presented a form in English with no Spanish translator; the officers told him to sign the form or he "would never get his daughter back" (Nawaz and Gretchen 2019, p. 1). The father claims that officers told him that they would be taken to an airport to reunite him with his daughter; instead, he was deported to Guatemala, and his daughter was sent to Guatemala City two months later (Nawaz and Gretchen 2019).

In May of 2018, Vilma Carrillo, a Guatemalan migrant, was separated from her daughter Yeisvi, a U.S. citizen (Jordan 2018). Carrillo came to the U.S. for the first time because her husband was beating her and so she applied for political asylum. Under the Trump administration, domestic abuse is no longer legal grounds for seeking asylum. CBP detained Carrillo while she was reentering the U.S. after she travelled to Guatemala to bury her mother and to pick up her daughter, who was living with her mother. CBP claims, "when a removable foreign national arrives in the United States with a U.S. citizen minor, the minor must be permitted to enter while the foreign national is processed" (Jordan 2018, p. 1). Thus, Carrillo was placed in detention in Georgia while Yeisvi was placed with Rosa Fernandez, who is currently fostering the child. Carrillo appeared in court on August of 2018 and was denied stay in the U.S. in spite of her prior political asylum application. She is unable to communicate because of her Mayan dialect and lack of representation. Carrillo could lose her parental rights, and her daughter will likely be placed for adoption (Jordan 2018). 
Child-family separation from ICE raids are occurring more frequently with the most recent and largest, single-state immigration raid occurred in Mississippi (Ainsley and Martinez 2019). About 680 undocumented immigrants were arrested in seven food-processing plants, leaving many children emotionally devastated with the uncertainty of when they will see their biological parents again (Gallagher 2019). An 11-year-old child named Magdalena Gomez Gregorio stated, "I need my dad and mommy. My dad didn't do nothing, he's not a criminal" (Gallagher 2019, p. 1). Tony McGee, a Mississippi school district superintendent, knew at least six families affected in the raids and expected that number to increase in the following days. McGee is trying his best for every affected child to arrive "home safe or [to have] a safe place to go" (Fowler 2019). President Trump admitted that these raids serve as a "very good deterrent" for undocumented immigrants wanting to settle in the United States (Ainsley and Martinez 2019, p. 1). To help the affected children, a school district advised the bus drivers not to drop off children if a guardian is not seen at the bus stop. The children would be brought back to the school for the night. An ICE official stated, "We are a law enforcement agency, not a social services agency," arguing that a notification to welfare agencies would have compromised the operation to round up undocumented immigrants in the food-processing plants (Ainsley and Martinez 2019, p. 1). The ICE operation had little consideration for the general and emotional care of the affected children, causing the local community to step up and to ensure that the children had a safe place to stay (Ainsley and Martinez 2019).

\subsubsection{Cases of No Reunification in Sight}

The "loopholes" in the immigration system explained earlier made it possible that more than 700 families were separated in the past year. When biological parents have any type of minor criminal convictions or any health concerns, if a nonbiological parent is accompanying the children, or if the parent is under 18 years old, both child and parent are separated at apprehension. The British Broadcasting Corporation (BBC News 2019) provided the stories of 100 children still separated in spite of a judge's order for reunification with their families for these various reasons. Although there is a 4-percent increase in child separation for children under 5 years old, a DHS officer claimed that family separations were "extraordinarily rare", with only adult guardians that pose a high risk of being separated from their children (Sacchetti 2019). Regarding the zero-tolerance policy, the Trump administration failed to reunite all 102 children-separated families during the summer of 2018 (King 2018); only 38 of them were reunited. The reason many of these children have not been reunited with their biological parents is because they have been placed in "nearly 20 different states and their birth parents have already been deported" (King 2018, p. 1).

The Trump administration claimed that it could link thousands of migrant families together that were separated at the U.S. border. This was proven to be wrong when emails from the U.S. government had only sufficient information to link approximately 60 families (Soboroff 2019, p.1). At the time, close to 3000 children were in custody, and it can be concluded that about 250 would be placed into a new family because their biological parents would be deported. The Trump administration claims that children under 5 years old are unlikely to reunite with their biological parents. With families failing to be reunited, it has become clear that the government does not have a diligent tracking system (Soboroff 2019). Twelve of the biological parents in local jails or federal custody are unlikely to be reunited with their children now placed in the care of unrelated families (King 2018). A Young Center for Immigrant Children's Rights spokesperson claims that DHS officials who have little child welfare expertise are "making split-second decisions" that will have "traumatic, lifelong consequences for the children and their families" (Sacchetti 2019, p. 1).

\subsubsection{Cases of Definitive or Temporary Loss of Parental Rights}

A historical case of de facto adoption is that of Encarnacion Bail Romero, a mother from Guatemala, who was arrested in 2007 for using another person's social security number while working at a poultry farm in Missouri. As a result, her 6-month-old son was placed with a foster family and eventually 
put up for adoption. A district judge proposed that the child should remain with foster parents and that the biological mother had no right to see her son. After Romero lost parental rights while in custody, the Mosers became the adoptive parents of the boy when he was 11 months old (Castillo 2012; Redeen 2014; Ross and Hill 2012). The attorney of the Moser family is "happy about the decision" and states that the decision "puts the biological mom in a difficult decision in terms of staying in this country" (Ross and Hill 2012, p. 1). The Supreme Court of Missouri put the Mosers' adoption on hold, and a retrial for the case was granted. The court cases resulted in Romero losing her right to see her child because she abandoned her child, and the Moser family's adoption would proceed. The Mosers' attorney claimed that Romero was an "unfit mother" and would not provide a stable life for the child. Romero had not seen her son since she was detained (Castillo 2012). During trials, Romero obtained temporary visas while seeking child custody and was represented by the National Immigrant Women's Advocacy Project, the Consulate General of Guatemala, the American Civil Liberties Union, and the Mexican American Legal Defense and Education Fund. In 2014, the Supreme Court declined to hear Romero's appeal and terminated her parental rights. By then, the child was 7 years old and had lived most of his life with the Mosers (Redeen 2014).

Another well-known case is that of Alexa, a baby of 10 weeks who was separated from her mother Araceli Ramos Bonilla when fleeing El Salvador and crossing the border in November 2015 (Associated Press 2018), before the zero-tolerance policy. The ORR and Bethany Christian Services placed Alexa with foster parents Sherri and Kory Barr, who were later granted temporary guardianship of then 2-year-old toddler by a Michigan court. According to Bethany, "since the 1980s ... nine of the 500 migrant children assigned to its foster program have been adopted by American families ... adopted after it was determined it wouldn't be safe or possible for them to go back to their families; at least one asked to be adopted by his foster parents, and another was a trafficking victim" (Associated Press 2018, p. 1). This nongovernmental agency has been found to be associated with the family of the U.S. Secretary of Education Betsy DeVos and was scrutinized for engaging in forced family separation as part of a government contract paying Bethany $\$ 700$ per night per child for the temporary care of unaccompanied minors (MacGill 2018). After a legal battle of the deported biological mother, the court determined that the "temporary guardianship order is in violation of federal law," and the Barrs were ordered to return Alexa to El Salvador (MacGill 2018, p. 1).

\section{Discussion}

This section summarizes the patterns in the treatment of migrant children and their families in the U.S., including the patterns in policy-making and management of the agencies and facilities entrusted to their care. It focuses on the implications of the prolonged detention and forced separation of migrant children and their families, regarding the protection, development, and well-being of child migrants. Drawn from this analysis are key lessons learned from transnational adoption and kinship care that may be applicable to the increased child migration to the U.S. and throughout the globe.

\subsection{Patterns, Policy Options, and Administrative Hurdles for Children in Current U.S. Systems}

El Salvador, Guatemala, and Honduras are nations with rising numbers of unaccompanied minors migrating to the United States. These northern triangle countries of Central America face many issues like poverty, violence, and inequality of women that serve as push factors for many migrants to make the dangerous trip to the United States (U.S. Government Accounting Office 2015). The study found that the large influx has created an adverse impact on an already broken immigration system. In the current system, unaccompanied minors and children declared as such because it was not possible to determine the relationship with the caretaker with whom they were traveling are transferred to the ORR until they are moved to safe sponsor settings. However, as documented in a 218-page court filing, family separations have continued since the court order of June 2018 (Gonzales 2019). Furthermore, children in detention have been held for longer than permitted under the Flores agreement (over 20 days); they have not been provided with essential personal hygiene products. A June 2019 court 
ruling confirmed that "authorities had failed to provide safe and sanitary conditions for the children under the 1997 settlement" (Associated Press 2019, p. 1).

The Center for Gender and Refugee Studies of the University of California Hastings College and the Migration \& Asylum Program Justice and Human Rights Center of the National University of Lanús (2015) concluded that the problem is not solved when the families return to their homelands, where violence and poverty are rampant and basic human rights are not met. U.S. federal law mandates that unaccompanied children of Mexico must be placed into federal custody if they are at a high risk of voluntarily returned back to their home country of Mexico. U.S. Customs and Border Protection (CBP) releases most of the Mexican children it apprehends without considering the risk they face if returned to their country of origin. Instead, CBP repatriates nearly all Mexican children and adolescents it apprehends under the presumption that they are not at risk. The unaccompanied minors in U.S. custody are often being deprived of their human rights at the federal and international levels. CBP officers and conditions in holding cells violate children's rights under federal law and international human rights law. CBP agents have been found to have abused children and adolescents verbally, physically, or sexually. Migrant minors continue to be placed in unsanitary facilities lacking adequate heating systems and bedding that fails to meet health standards for proper nutrition and that have limited recreation and medical attention.

To address the growing border concerns, President Trump pushed for a $\$ 4.5$ billion emergency fund. After contested debates over how this emergency request would grant protection for children, the bill passed both the House and the Senate and President Trump signed it on July 1, 2019. A major concern when considering additional funding was if relevant agencies were going to be allowed to detain families longer and to deport them faster; in fact, immigration detention centers were reaching their maximum capacity and becoming unequipped to handle the increasing number of migrant families (Merchant 2019). As evident in the individual cases analysed here, ongoing violations of FSA and TVPRA when processing migrant children have been documented. Where there are questions about the biological parents' claim for asylum, thus requiring them to wait for expedited procedures, children may be separated from their biological parents by declaring them UACs and by not withholding them for more than 20 days. Given the shortage of state-licensed Family Residential Centers (FRCs), when children but not their biological parents are found admissible, they are separated and placed in child-friendly facilities. FRCs were not part of the most recent OIG investigation regarding child migrant detention conditions (DHS 2018). The report concluded that "Neither type of inspection ICE uses to examine detention facilities ensures consistent compliance with detention standards or comprehensive correction of identified deficiencies" (DHS 2018, p. 4). Given the FRC shortage, a recent DHS/DHHS ruling "proposed that where state licensing is unavailable, a facility will be licensed if DHS employs an outside entity to ensure that the facility complies with family residential standards established by ICE" (U.S. Office of the Federal Registrar 2019, p. 44394). Although this new ruling mandates U.S. government agencies to abide by the FSA and TVPRA protections to child migrants, it does not seem to prevent child-family separations, to prevent prolonged immigrant detentions, and to guarantee adequate care of minors when in government custody. The analysis of individual cases in this article point to these and other system failures.

\subsection{Implications for the Protection, Development, and Well-Being of Child Migrants in the U.S.}

The inhumane treatment of immigrants in detention and of children in particular explain why there have been cases of minors dying in U.S. custody. The Center for Gender and Refugee Studies of the University of California Hastings College and the Migration \& Asylum Program Justice and Human Rights Center of the National University of Lanús (2015) found that children migrating from Central America are experiencing human rights violations and institutional violence. Children who migrate to Mexico often face trauma when the government sector and organized criminals abuse the children physically and sexually. The U.S. has immigration policies in place to discourage migration rather than to protect the basic human rights of the minors. Unaccompanied minors who have family 
members with varying legal statuses in the U.S. fear the separation and deportation of their loved ones. When the biological parents of a migrant child are deported, it is often not taken into consideration whether it is the best outcome for the child.

Thus, it is critical to understand that child-family separation by death undermines the fundamental right of children to live, which is upheld in the CRC. The youngest child who has experienced child-parent separation in the U.S. was 4 months old from Romania (Constantin Mutu) who was returned to his family after four months of separation (Dickerson 2019). However, the prolonged separation of Central American children from their biological parents and their separation with no reunification in sight has become a gross form of violation of the fundamental rights of children and is considered not only in the CRC and HCIA but also in the U.N. Guidelines for the Alternative Care of Children. Placement with extended family members and informal, family-based care options are preferred over domestic or intercountry adoptions (Bunkers 2010), including de facto adoption.

The determination of the best interest of the child in the individual cases analysed was difficult because the concept of "psychological parenting" carries substantial weight in U.S. courts when solving cases of this type. In fact, the "child's lack of contact with his or her national culture may weigh against the natural parents because of the difficulties associated with adjustment from an American family setting to the former cultural setting" (Durkee 1982, p. 211). This became evident in the numerous litigations of repatriation of presumed orphans adopted by U.S. families during the 1975 "Operation Babylift" from Vietnam (Durkee 1982).

The child welfare system in the U.S. has three goals: protection, permanence, and well-being; these "tenets (as articulated by the Children's Bureau in 1998) form the foundation of child welfare practice" (U.S. Department of Health and Human Services 2013, p. 1). The American Psychological Association (American Psychological Association 2013) confirms that "Child protection laws [in the U.S.] address three interests: the child's, the [biological] parents', and the state's. Child protection laws emphasize that the child has a fundamental interest in being protected from abuse and neglect" (p. 20). Even if these tenets and standards were established to prevent child maltreatment in the U.S., they do not seem to apply to child migrants. As discussed next, an approach centered on the best interest of immigrant children in the U.S. would imply that immigration policies, agencies, and procedures are aligned with the goals of the child welfare system (U.S. Department of Health and Human Services 2019a) in order to ensure the protection, permanence, and well-being of migrant children in the U.S.

\subsection{A Child Rights-Based Approach to the Care of Migrant Children in the U.S.}

Roby (2007) proposes a child rights continuum before, during, and after adoption. Before adoption, children's rights include the right to life, to maternal and prenatal care, and to health care; the right to grow up in a family; and the right to grow up in one's own culture. During adoption, children's rights include the right to a determination of adoptability, the right to be placed with a properly prepared adoptive family, the right to be matched with families who can and will provide for special needs, the right of protection from becoming a commodity, the right to competent and ethical professional care, and the right to give consent or to express one's own opinion. After adoption, children's rights include the right to full family membership, the right to social acceptance, and the right to have access to birth and identity records (Roby 2007).

The application of Roby's child rights-based approach to the migrant children crossing the U.S. border would imply following the child rights continuum of before, during, and after detention and institutional care. In applying this approach, both the best interest of the child as well as the principle of subsidiarity must be observed in making choices regarding the suitability of parents to care for the children, the most appropriate alternative care while reunification is enabled, and the most secure placement of children if reunification does not take place. An analysis of the individual case studies presented in this article suggests that the lack of a child rights-based approach in the U.S. regarding migrating children from the Central American northern triangle has resulted in indefinite or prolonged separation, institutionalization, or de facto adoption. 
An important lesson learned from the intercountry adoption evolution is that defining human rights with respect to ICAs "is a complex task due to the legal, cultural, and social diversity of the sending and receiving nations" (Roby and Ife 2009, p. 665). Drawing on social welfare and globalization theories, Dickens (2009) confirmed the dynamic interaction of "national child and family welfare policies in receiving and sending countries" (p. 595). Thus, the observance of international standards is important yet the national local context in which any adoption takes place is critical to securing the children's rights. In addition, pre- and postadoption services are critical to overcome the deprivation, neglect, and abuse, resulting in severe physical illnesses, attachment disorders, and other serious health, behavioral, and development problems that adopted children tend to manifest (Welsh et al. 2007). Although, in the past, migrant children under government care have not been adoptable, local courts are likely to grant adoption to foster families or guardians as these minors remain separated from their biological parents through longer detention or deportation.

Biological parents migrating to the U.S. have limited parental rights once their child goes into government care, whether that is in detention facilities or in foster family placements. Child-family separation cases are not resolved until reunification in U.S. soil or their country of origin (via deportation) or until the rights of biological parents are dissolved. Their prolonged detention and the lack of reunification or formal adoption make these children stateless, which is another violation of their rights upheld in both the CRC and the HCIA. For the children not reunified with their biological parents after separation during the zero-tolerance policy, they are denied access to their biological parents and to their cultural identity. A major challenge that migrant children seeking asylum in the U.S. face is the U.S. not observing its own child protection standards, much less international standards, including those upheld in the HCIA and in the CRC.

\section{Conclusions}

The historical "quiet" migration of Central American children to the U.S. through intercountry adoption has been ignited by organized crime networks, involving government officials and inadequate child protection laws. The more recent migration of children and their families seeking asylum in the U.S. is due to gang violence, domestic violence, and poverty. These constitute the main push factors of migration from the region, which leaves many immigrants with no option but to migrate. In their search for refuge, migrant children and their families travel through different countries and dangerous routes with the help of human smugglers, who charge them thousands of dollars per person and even subject them to human trafficking. Immigrants traveling with children have been turning themselves for apprehension by U.S. border authorities in order to apply for asylum in the U.S. Recently, they have been sent to "safe third" countries, which are the same unsafe countries through which they travelled or departed from.

The current U.S. policies and facilities have failed to respect the basic human rights of children and families. The U.S. immigration agencies are embedded in a broken tracking system that impedes the reunification of migrant family. The Trump administration enforced the zero-tolerance policy, whereby any individual who crosses the U.S. border will be prosecuted. Family separation has been used to punish those entering without border patrol inspection, and migrant children have been placed in the custody of a sponsor, shelter, or foster care. Placing children into inhumane facilities, separating families, relocating them into different facilities from their parents, and holding them for long periods of time than allowed by law are ways in which the U.S. government violates the basic human rights of immigrant children and their families.

The current U.S. immigration system creates the conditions in which immigrant parents detained in the southern U.S. border lose their parental rights if they are considered to pose a risk or deemed unfit to take care of their children. Parents who have past records of misdemeanors, disabilities, or other small acts have faced separation from their children. Parents have reported that they have been misinformed and pressured to accept temporary separation and placement of their children in special facilities and to accept voluntary deportation to ensure their children are not deported. 
These children are placed in facilities with other children or with foster parents. These measures are intentionally implemented to bring fear, to question cultural background, and to manipulate the mental and emotional well-being of migrant children and their families.

Through individual case studies, the authors have offered a characterization of the various ways in which child-family separation is taking place. Both country-level and individual case studies described the experience of migration from this subregion of Central America. In the cases examined here, the readjustment of the child to the country of reception or origin seems to have taken place without major anomalies in terms of child development and well-being. In all forms of child-family separation, the best interest of the child seems to override the principle of subsidiarity, even in the presence of forced family separation and of fraud, force, and coercion in guardianship and adoption. Although the evidence presented here is not sufficient to make generalizable conclusions, the case study data collected revealed how the historical evolution of intercountry adoption from Central America to the U.S. has been intertwined with the large immigration of children and their families to the U.S. from that region in the past few years.

Author Contributions: Conceptualization, C.M.; methodology, C.M.; formal analysis, C.M. and J.M.-S.; investigation, C.M. and J.M.-S.; writing - original draft preparation, C.M. and J.M.-S.; writing-review and editing, C.M. and J.M.-S.; supervision, C.M.

Funding: This research received no external funding.

Acknowledgments: We are grateful to Karen S. Rotabi, Chair and Professor of the Department of Social Work at California State University-Monterey Bay, and to Kathryn M. Doan, Esq., Executive Director of the Capital Area Immigrants' Rights Coalition (CIAR), for their useful comments to the manuscript. They have expertise in intercountry adoption and immigration law, respectively. Special thanks to Maya Porter for her professional editing of the manuscript.

Conflicts of Interest: The authors declare no conflict of interest.

\section{References}

ACLU. 2018a. ACLU to court: Order the Government to Reunite the Families. Available online: https://www.aclu.org/blog/immigrants-rights/immigrants-rights-and-detention/aclu-court-ordergovernment-reunite-families (accessed on 2 December 2019).

ACLU. 2018b. No, the Government Did Not Make the Deadline to Reunify Children with Their Parents. Available online: https:/www.aclu.org/blog/immigrants-rights/immigrants-rights-and-detention/no-governmentdid-not-make-deadline-reunify (accessed on 2 December 2019).

ACLU. 2018c. Fact-Checking Family Separation. Available online: https://www.aclu.org/blog/immigrants-rights/ immigrants-rights-and-detention/fact-checking-family-separation (accessed on 2 December 2019).

ACLU. 2018d. Family Separation by the Numbers. Available online: https://www.aclu.org/issues/immigrantsrights/immigrants-rights-and-detention/family-separation (accessed on 2 December 2019).

Ainsley, Julia, and Didi Martinez. 2019. What ICE did and did not do for kids left behind by Mississippi raids. NBC News. August 9. Available online: https://www.nbcnews.com/politics/immigration/what-ice-did-didnot-do-kids-left-behind-mississippi-n1040776?cid=emlnbn20190809 (accessed on 2 December 2019).

Alstein, Howard, and Rita J. Simon. 1991. Intercountry Adoption-A Multiple Perspective. New York: Praeger.

American Psychological Association. 2013. Guidelines for psychological evaluations in child protection matters. American Psychological Association 68: 20-31. [CrossRef] [PubMed]

Associated Press. 2018. Deported parents may lose kids to adoption, investigation finds. NBC News. October 9. Available online: https://www.nbcnews.com/news/latino/deported-parents-may-lose-kids-adoptioninvestigation-finds-n918261 (accessed on 2 December 2019).

Associated Press. 2019. Soap, sleep essential to migrant kids' safety, according to panel of judges. Public Broadcasting Service. August 15. Available online: https://www.pbs.org/newshour/nation/soap-sleep-essential-to-migrantkids-safety-according-to-panel-of-judges (accessed on 2 December 2019).

Ataiants, Janna, Chari Cohen, Amy Henderson Riley, Jamile Tellez Lieberman, Mary Clare Reidy, and Mariana Chilton. 2018. Unaccompanied children at the United States border, a human rights crisis 
that can be addressed with policy change. Journal of Immigrant and Minority Health 20: 1000-10. [CrossRef] [PubMed]

BBC News. 2018. Honduras country profile. BBC News. May 16. Available online: https://www.bbc.com/news/ world-latin-america-18954311 (accessed on 2 December 2019).

BBC News. 2019. Migrant children in the US: The bigger picture explained. BBC News. July 2. Available online: https://www.bbc.com/news/world-us-canada-44532437 (accessed on 2 December 2019).

Bromfield, Nicole Footen, and Karen Smith Rotabi. 2012. Human trafficking and the Haitian child abduction attempt: Policy analysis and implications for social workers and NASW. Journal of Social Work Values and Ethics 9: 1-25.

Bunkers, Kelley McCreery. 2010. Informal Family-Based Care Options: Protecting Children's Rights? A Case Study of Gudifecha in Ethiopia. Master's of Advanced Studies in Children's Rights dissertation, Institut Universitaire Kurt Bosch and Université de Fribourg, Geneva, Switzerland.

Bunkers, Kelly McCreery, and Victor Groza. 2012. Intercountry adoption and child welfare in Guatemala: Lessons learned pre and post ratification of the 1993 Hague Convention on the Protection of Children and Cooperation in Respect of Intercountry Adoption. In Intercountry Adoption: Policies, Practices, and Outcomes. Edited by Judith L. Gibbons and Karen Smith Rotabi. Surrey: Ashgate Press, pp. 119-31.

Bunkers, Karen McCreery, Victor Groza, and Daniel Lauer. 2009. International adoption and child protection in Guatemala: A case of the tail wagging the dog. International Social Work 52: 649-60. [CrossRef]

Burnett, John, and Vanessa Romo. 2019. Guatemalan toddler apprehended at U.S. border dies after weeks in hospital. National Public Radio. May 16. Available online: https://www.npr.org/2019/05/ 16/723984077/guatemalan-toddler-apprehended-at-u-s-border-dies-after-weeks-in-hospital (accessed on 2 December 2019).

Castillo, Mariano. 2012. Undocumented immigrant mother loses adoption battle. CNN. July 18. Available online: https://www.cnn.com/2012/07/18/us/missouri-immigrant-child/index.html (accessed on 2 December 2019).

Catholic Legal Immigration Network, Public Counsel, Goodwin Procter LLP, and Kids in Need of Defense (KIND). 2019. Court Order Blocks New Asylum Policy Affecting Unaccompanied Immigrant Children. August 5. Available online: https://supportkind.org/media/court-order-blocks-new-asylum-policy-affectingunaccompanied-immigrant-children/ (accessed on 2 December 2019).

Center for Gender and Refugee Studies of the University of California Hastings College and the Migration \& Asylum Program Justice and Human Rights Center of the National University of Lanús. 2015. Childhood and Migration in Central and North America: Causes, Policies, Practices and Challenges. Available online: https://www.justice.gov/eoir/file/882926/download (accessed on 2 December 2019).

Chapin, Angelina. 2019. In their own words, migrant children describe horrific conditions at border patrol facilities. HuffPost. June 28. Available online: https://www.huffpost.com/entry/migrant-children-describedetention_n_5d1646ffe4b03d61163af666 (accessed on 2 December 2019).

CICIG. 2010. Report on Players Involved in the Illegal Adoption Process in Guatemala Since the Entry into Force of the Adoption Law (Decree 77-2007). Available online: http://cicig.org/uploads/documents/informes/INFORTEMA_DOC05_20101201_EN.pdf (accessed on 2 December 2019).

DHS. 2018. ICE's inspections and monitoring of detention facilities do not lead to sustained compliance or systemic improvements. Office of Inspector General. Available online: https://www.oig.dhs.gov/sites/default/files/ assets/2018-06/OIG-18-67-Jun18.pdf (accessed on 2 December 2019).

Dickens, Jonathan. 2009. Social Policy Approaches to Intercountry Adoption. International Social Work 52: 595-607. [CrossRef]

Dickerson, Caitlin. 2019. The youngest child separated from his family at the border was 4 months old. The New York Times. June 16. Available online: https://www.nytimes.com/2019/06/16/us/baby-constantine-romaniamigrants.html?action=click\&module=RelatedLinks\&pgtype=Article (accessed on 2 December 2019).

Durkee, Ellen. 1982. Special problems of custody for unaccompanied refugee children in the United States. Michigan Journal of International Law 3: 197-225.

Durran, Mary. 1993. New Internationalist. Stealing Children: Northern Couples Who "Legally" Adopt Children from Honduras May Never Imagine That the Children Have Been Stolen from Their Mothers. Available online: https://www.questia.com/read/1P3-450770921/stealing-children-northern-couples-who-legally (accessed on 2 December 2019). 
Engel, Eliot L. 2019. Chairmen Engel, Nadler, and Thompson call on Trump to end Unlawful Safe Third Country Negotiations: State Department Human Rights Report Shows Guatemala and Mexico Agreements Would be Contrary to U.S. Law. June 27. Available online: https://engel.house.gov/latest-news/chairman-engel-nadlerand-thompson-call-on-trump-to-end-unlawful-safe-third-country-negotiations/ (accessed on 2 December 2019).

Estefan, Lianne Fuino, Katie A. Ports, and Tracy Hipp. 2017. Unaccompanied Children Migrating from Central America: Public Health Implications for Violence Prevention and Intervention; Betseda: National Center for Biotechnology Information. Available online: https://www.ncbi.nlm.nih.gov/pmc/articles/PMC5812021/ (accessed on 2 December 2019).

Filipovic, Jill. 2019. I can no longer continue to live here. Politico Magazine. Available online: https://www.politico.com/magazine/story/2019/06/07/domestic-violence-immigration-asylumcaravan-honduras-central-america-227086 (accessed on 2 December 2019).

Fowler, Sarah. 2019. Where are my parents? School on standby to help children in aftermath of ICE raids. USA Today. Available online: https:/www.usatoday.com/story/news/nation/2019/08/08/ice-raidsmississippi-undocumented-workers-arrested-kids-worry/1952572001/?fbclid=IwAR1ZdRhA4e0Evcknt\% 20Hhf5k2bX0hEVVXgv\%20AD2IFIczD0pzgWI5QIhHEg_Irg (accessed on 2 December 2019).

Gallagher, Dianne. 2019. 680 undocumented workers arrested in record-setting immigration sweep on the first day of school. CNN. Available online: https://www.cnn.com/2019/08/08/us/mississippi-immigration-raidschildren/index.html (accessed on 2 December 2019).

Gendle, Matthew H., and Carmen C. Monico. 2017. The balloon effect: The role of US drug policy in the displacement of unaccompanied minors from the Central American northern triangle. Journal of Trafficking, Organized Crime and Security 3: 12-20.

Goldschmidt, Ilse. 1986. National and intercountry adoptions in Latin America. International Social Work 29: 257-68. [CrossRef]

Gonzales, Richard. 2019. ACLU: Administration is still separating migrant families despite court order to Stop. National Public Radio. July 30. Available online: https://www.npr.org/2019/07/30/746746147/acluadministration-is-still-separating-migrant-families-despite-court-order-to-?utm_campaign=storyshare (accessed on 2 December 2019).

Gzesh, Susan. 2019. "Safe Third Country" agreements with Mexico and Guatemala would be unlawful. Just Security. July 15. Available online: https://www.justsecurity.org/64918/safe-third-country-agreements-withmexico-and-guatemala-would-be-unlawful/ (accessed on 2 December 2019).

Haag, Matthew. 2019. Thousands of immigrant children said they were sexually abused in U.S. detention centers, report says. The New York Times. Available online: https://www.nytimes.com/2019/02/27/us/immigrantchildren-sexual-abuse.html (accessed on 2 December 2019).

HCCH. 1993a. Convention of 29 May 1993 on Protection of Children and Co-Operation in Respect of Intercountry Adoption. Available online: https://www.hcch.net/en/instruments/conventions/full-text/?cid=69 (accessed on 2 December 2019).

HCCH. 1993b. Explanatory Report on the 1993 Hague Intercountry Adoption Convention. Available online: https://www.hcch.net/en/publications-and-studies/details4/?pid=2279 (accessed on 2 December 2019).

HCCH. 2008. Guatemala: Annual Adoption Statistics 1997-2005. Available online: http://hcch.e-vision.nl/upload/ adostats_gu.pdf (accessed on 2 December 2019).

HCCH. 2011. Status Table 33: Convention of 29 May 1993 on Protection of Children and Co-operation in Respect of Intercountry Adoption. Available online: https:/www.hcch.net/en/instruments/conventions/status-table/ ?cid=69 (accessed on 2 December 2019).

Hennessy-Fiske, Molly. 2019. Guatemalan 16-year-old boy dies in U.S. custody after crossing the border. Los Angeles Times. Available online: https://www.latimes.com/nation/la-na-border-migrant-youth-death-20190501-story. html (accessed on 2 December 2019).

Herrmann, Kenneth, and Barbara Kasper. 1992. International adoption: The exploitation of women and children. Affilia 7: 45-58. [CrossRef]

Hollingsworth, Lselie Doty. 2003. International adoption among families in the United States: Considerations of social justice. Social Work 48: 209-17. [CrossRef]

Human Rights Watch. 2018. Honduras Events of 2018. Available online: https:/www.hrw.org/world-report/2019/ country-chapters/honduras (accessed on 2 December 2019). 
Ingber, Sasha. 2019. Third child dies in U.S. government custody since December. National Public Radio. Available online: https://www.npr.org/2019/05/02/719409488/third-child-dies-in-u-s-government-custodysince-december (accessed on 2 December 2019).

Instituto Latinoamericano para la Educación y la Comunicación, ILPEC [Latin American Institute for Education and Communication]. 2000. Adopción y los derechos del niño en Guatemala [Adoption and the rights of the child in Guatemala]. Available online: https://www.brandeis.edu/investigate/adoption/docs/ InformedeAdopcionesFundacionMyrnaMack.pdf (accessed on 2 December 2019).

Jawetz, Tom, and Scott Shuchart. 2019. Language access has life-or-death consequences for migrants. Center for American Progress. Available online: https://www.americanprogress.org/issues/immigration/reports/2019/02/ 20/466144/language-access-life-death-consequences-migrants/ (accessed on 2 December 2019).

Jordan, Miriam. 2018. 'It's horrendous': The heartache of a migrant boy taken from his father. The New York Times. Available online: https://www.nytimes.com/2018/06/07/us/children-immigration-borders-family-separation. html (accessed on 2 December 2019).

King, Shaun. 2018. Encarnación Bail Romero's story is a harrowing reminder of the stakes for separated migrant families. The Intercept. Available online: https://theintercept.com/2018/07/11/separated-children-encarnacionbail-romero/ (accessed on 2 December 2019).

Rocio, Labrador, and Danielle Renwick. 2018. Central America's violent northern triangle. Council on Foreign Relations. June 26. Available online: https://www.cfr.org/backgrounder/central-americas-violent-northerntriangle (accessed on 2 December 2019).

MacGill, Dan. 2018. Christian non-profit faces scrutiny over government foster care contract for separated children. Snopes News. June 26. Available online: https://www.snopes.com/news/2018/06/26/bethanychristian-services-family-separation-betsy-devos/ (accessed on 2 December 2019).

MacLean, Sarah A., Priscilla O. Agyeman, Joshua Walther, Elizabeth K. Singer, Kim A. Baranowski, and Craig L. Katz. 2019. Mental health of children held at a United States immigration detention center. Social Science $\mathcal{E}$ Medicine 230: 303-8. [CrossRef]

Merchant, Nomaan. 2019. 4th migrant child dies in U.S. custody since December. Public Broadcasting Service. Available online: https://www.pbs.org/newshour/nation/4th-migrant-child-dies-in-u-s-custodysince-december (accessed on 2 December 2019).

Monico, Carmen. 2013. Implications of Child Abduction for Human Rights and Child Welfare Systems: A Constructivist Inquiry of the Lived Experience of Guatemalan Mothers Publically Reporting Child Abduction for Intercountry Adoption. Ph.D. dissertation, Virginia Commonwealth University, Richmond, VA, USA. Available online: http://hdl.handle.net/10156/4373 (accessed on 2 December 2019).

Monico, Carmen, and Karen Smith Rotabi. 2012. Truth, reconciliation and searching for the disappeared children of civil war: El Salvador's search and reunion model defined. In Intercountry Adoption: Policies, Practices, and Outcomes. Edited by Judith L. Gibbons and Karen Smith Rotabi. Surrey: Ashgate, pp. 301-10.

Monico, Carmen, Karen Smith Rotabi, and Justin Lee. 2019a. Forced child-family separations on the southwestern U.S. border under the "zero-tolerance" policy: Preventing human rights violations and child abduction into adoption (Part 1). Journal of Human Rights and Social Work 4: 164-79. [CrossRef]

Monico, Carmen, Karen Rotabi, Yvonne Vissing, and Justin Lee. 2019b. Forced child-family separations in the southwestern U.S. border under the "zero-tolerance" policy: The adverse impact on well-being of migrant children (Part 2). Journal of Human Rights and Social Work 4: 180-91. [CrossRef] 
Nawaz, Amna, and Frazee Gretchen. 2019. 'Why did you leave me?' In new testimonies, migrants describe the 'torment' of child separation. PBS. Available online: https://www.pbs.org/newshour/nation/whydid-you-leave-me-in-new-testimonies-migrants-describe-the-torment-of-child-separation (accessed on 2 December 2019).

O'Halloran, Kerry, ed. 2006. Intercountry adoption. In The Politics of Adoption. Amsterdam: Springer, pp. $263-89$.

Polaris. n.d. Current Federal Laws. Available online: https://polarisproject.org/current-federal-laws (accessed on 2 December 2019).

Public Law 96-212. 1980 March 17. Available online: https://www.govinfo.gov/content/pkg/STATUTE-94/pdf/ STATUTE-94-Pg102.pdf (accessed on 2 December 2019).

Rappleye, Hannah, and Lisa Riordan Seville. 2019. 24 immigrants have died in ICE custody during the Trump administration. NBC News. June 9. Available online: https://www.nbcnews.com/politics/immigration/24immigrants-have-died-ice-custody-during-trump-administration-n1015291 (accessed on 2 December 2019).

Redeen, Susan. 2014. U.S. Supreme Court declines to consider area adoption case. The Joplin Globe. Available online: https://www.joplinglobe.com/news/local_news/u-s-supreme-court-declines-to-considerarea-adoption-case/article_3479fa7a-11a9-5d87-a08b-613608d32e45.html (accessed on 2 December 2019).

Reichert, Elizabeth. 2003. Social Work and Human Rights: A Foundation for Policy and Practice. New York: Columbia University.

REMHI [Recuperación de la Memoria Histórica or Recovery of the Historical Memory]. 1999. Guatemala Never again! Maryknoll: Orbis.

Roby, Jini L. 2007. From rhetoric to best practice: Children's rights in intercountry adoption. Children's Legal Rights Journal 27: 48-71.

Roby, Jini L., and Jim Ife. 2009. Human rights, politics and intercountry adoption: An examination of two sending countries. International Social Work 52: 661-71. [CrossRef]

Roby, Jini L., Karen Smith Rotabi, and Kelly McCreery Bunkers. 2013. Social justice and intercountry adoptions: The role of the U.S. social work community. Social Work 58: 295-303. [CrossRef]

Root, Jay. 2019. How one migrant family got caught between smugglers, the cartel and Trump's zero-tolerance policy. The Texas Tribune. Available online: https://www.texastribune.org/2019/03/07/migration-us-bordergenerating-billions-smugglers/ (accessed on 2 December 2019).

Ross, Brian, and Angela M. Hill. 2012. Tug-of-love: Immigrant mom loses effort to regain son given to US parents. In $A B C$ News. Available online: https://abcnews.go.com/Blotter/immigrant-mom-loses-effort-regain-son-usparents/story?id=16803067 (accessed on 2 December 2019).

Rotabi, Karen Smith. 2007. Ecological theory origin from natural to social science or vice versa? A brief conceptual history for social work. Advances in Social Work 8: 113-29. [CrossRef]

Rotabi, Karen Smith. 2009. Guatemala City: Hunger protests amid allegations of child kidnapping and adoption fraud. Social Work and Society News Magazine. Available online: http://www.socmag.net/?p=540 (accessed on 2 December 2019).

Rotabi, Karen Smith, and Kelly McCreery Bunkers. 2008. Intercountry adoption reform based on the Hague Convention on Intercountry Adoption: An update on Guatemala in 2008. Social Work and Society News Magazine. Available online: http://www.socmag.net/?p=435 (accessed on 2 December 2019).

Rotabi, Karen Smith, Morris Alexandra W., and Weil Marie O. 2008. International child adoption in a post-conflict society: A multi-systemic assessment of Guatemala. Journal of Intergroup Relations 35: 9-41.

Rotabi, Karen Smith, Carmen Monico, and Kelly Bunkers. 2015. At this critical juncture in the era of reform: Reviewing 35 years of social work literature on intercountry adoption. In The Intercountry Adoption Debate: Dialogues Across Disciplines. Edited by Robert L. Ballard, Naomi H. Goodno, Robert F. Cochran and Jay A. Milbrandt. Newcastle upon Tyne: Cambridge Scholars Publishing.

Sacchetti, Maria. 2019. ACLU: U.S. has taken nearly 1,000 child migrants from their parents since judge ordered stop to border separations. The Washington Post. Available online: https://www.washingtonpost. com/immigration/aclu-us-has-taken-nearly-1000-child-migrants-from-their-parents-since-judge-orderedstop-to-border-separations/2019/07/30/bde452d8-b2d5-11e9-8949-5f36ff92706e_story.html (accessed on 2 December 2019).

Sanford, Victoria. 2003. Buried Secrets: Truth and Human Rights in Guatemala. New York: Palgrave Macmillan.

Sanford, Victoria. 2008. From genocide to feminicide: Impunity and human rights in twenty-first century Guatemala. Journal of Human Rights 7: 104-22. [CrossRef] 
Selman, Peter. 2002. Intercountry adoption in the new millennium: The "quiet migration" revisited. Population Research and Policy Review 21: 205-25. [CrossRef]

Selman, Peter. 2006. Trends in intercountry adoption: Analysis of data from 20 receiving countries, 1998-2004. Journal of Population Research 42: 183-204. [CrossRef]

Selman, Peter. 2009. The rise and fall of intercountry adoption in the 21st century. International Social Work 52: 575-94. [CrossRef]

Selman, Peter. 2012. The rise and fall of intercountry adoption in the 21st century: Global trends from 2001 to 2010. In Intercountry Adoption: Policies, Practices, and Outcomes. Edited by Justin Lee, Gibbons and Karen Smith Rotabi. London: Ashgate Press.

Sherman, Christopher, Martha Mendoza, and Garance Burke. 2019. US held record number of migrant children in custody in 2019. Associated Press. November 12. Available online: https://apnews.com/ 015702afdb4d4fbf85cf5070cd2c6824 (accessed on 2 December 2019).

Smolin, David Mark. 2005. Intercountry adoption as child trafficking. Valparaiso University Law Review 39: 281-325.

Smolin, David Mark. 2006. Child laundering: How the intercountry adoption system legitimizes and incentivizes the practices of buying, trafficking, kidnapping, and stealing children. Wayne Law Review 52: 113-200.

Smolin, David Mark. 2007. Intercountry adoption and poverty: A human rights analysis. Capital University Law Review 36: 413-53.

Smolin, David Mark. 2010. Child laundering and the Hague Convention on Intercountry Adoption: The future and past of intercountry adoption. Louisville Law Review 48: 441-98.

Soboroff, Jacob. 2019. Emails show Trump admin had 'no way to link' separated migrant children to parents. NBC News. Available online: https://www.nbcnews.com/politics/immigration/emails-show-trump-admin-hadno-way-link-separated-migrant-n1000746 (accessed on 2 December 2019).

Spencer, Hsu, and Thompson Steve. 2018. U.S. returns 7-year-old Guatemalan boy taken from his mother at border. The Washington Post. Available online: https://www.washingtonpost.com/local/public-safety/us-saysit-will-return-7-year-old-taken-from-guatemalan-mother-at-border-as-her-federal-lawsuit-gets-hearing/ 2018/06/21/cd20ffbe-7571-11e8-9780-b1dd6a09b549_story.html?noredirect=on\&utm_term=.21476fed38b7 (accessed on 2 December 2019).

8 U.S. Code $\$ 1158$ Asylum. 2008. Cornell Law School Legal Information Institute. Available online: https: //www.law.cornell.edu/uscode/text/8/1158 (accessed on 2 December 2019).

U.S. Department of Health and Human Services, 2013, Fact Sheet-How the Child Welfare System Works. Available online: https://www.childwelfare.gov/pubPDFs/cpswork.pdf (accessed on 2 December 2019).

U.S. Department of Health and Human Services. 2019a. Child welfare goals, legislation, and monitoring. Available online: https://training.cfsrportal.acf.hhs.gov/book/export/html/2987 (accessed on 2 December 2019).

U.S. Department of Health and Human Services. 2019b. Separated children placed in Office of Refugee Resettlement Care. In Office of Inspector General. Available online: https://oig.hhs.gov/oei/reports/oei-BL-18-00511.pdf (accessed on 2 December 2019).

U.S. Department of State. 2018. Annual Report on Intercountry Adoption. Available online: https:/travel.state.gov/content/dam/NEWadoptionassets/pdfs/Tab\%201\%20Annual\%20Report\% 20on\%20Intercountry\%20Adoptions.pdf (accessed on 2 December 2019).

U.S. Department of State. 2019. Adoptions Statistics. Available online: https://travel.state.gov/content/travel/en/ Intercountry-Adoption/adopt_ref/adoption-statistics.html (accessed on 2 December 2019).

U.S. Government Accounting Office. 2015. Central America: Information on migration of unaccompanied children from El Salvador, Guatemala, and Honduras. In GAO Highlights, GAO-15-362; Washington: Government Accounting Office. Available online: https://www.gao.gov/products/GAO-15-362 (accessed on 2 December 2019).

U.S. Office of the Federal Registrar. 2019. Apprehension, processing, care, and custody of alien minors and unaccompanied alien children. In Federal Register. Available online: https://www.govinfo.gov/content/pkg/FR-2019-08-23/pdf/2019-17927.pdf?fbclid=IwAR02E-mnrn6_ FJGyQzg0YuIgASLS-vG09pp3B4eaLsUQpy3ZiyXkkpqRcZo (accessed on 2 December 2019).

United Nations. 1948. Universal Declaration of Human Rights. Available online: http://www.un.org/en/ documents/udhr/ (accessed on 2 December 2019).

United Nations. 1989. Convention on the Rights of the Child. Available online: http://www2.ohchr.org/english/ law/pdf/crc.pdf (accessed on 2 December 2019). 
United Nations. 2000. Convention against Transnational Organized Crime and the Protocols Thereto. Available online: https://www.unodc.org/unodc/en/organized-crime/intro/UNTOC.html (accessed on 2 December 2019).

United Nations. 2010. Guidelines for the Alternative Care of Children. Available online: http://www.crin.org/ docs/Guidelines-English.pdf (accessed on 2 December 2019).

United Nations. 2014. Report of the Special Rapporteur on the Sale of Children, Child Prostitution and Child Pornography on Her Follow-Up Visit to Honduras (21-25 April 2014). Available online: https: //www.ohchr.org/Documents/Issues/Children/SR/A-HRC-28-56-Add1_ar.pdf (accessed on 2 December 2019).

United Nations Children's Fund (UNICEF). 2016. Broken Dreams: Central American Children's Dangerous Journey to the United States. Available online: https://www.unicef.org/infobycountry/files/UNICEF_Child_ Alert_Central_America_2016_report_final(1).pdf (accessed on 2 December 2019).

United Nations High Commissioner for Refugees. 2010. Convention and Protocol Relating to the Status of Refugees. Available online: https://www.unhcr.org/en-us/protection/basic/3b66c2aa10/convention-protocolrelating-status-refugees.html (accessed on 2 December 2019).

United Nations High Commissioner for Refugees. 2014. Children on the Run. Available online: http://www.unhcrwashington.org/sites/default/files/1_UAC_Children\%20on\%20the\%20Run_Full\% 20Report.pdf (accessed on 2 December 2019).

United Nations Human Rights Office of the High Commissioner. 2018a. Committee on the Rights of the Child Examines Report of El Salvador. Available online: https://www.ohchr.org/EN/NewsEvents/Pages/ DisplayNews.aspx?NewsID=23594\&LangID=E (accessed on 2 December 2019).

United Nations Human Rights Office of the High Commissioner. 2018b. Committee on the Rights of the Child Examines Report of Guatemala. Available online: https://www.ohchr.org/EN/NewsEvents/Pages/ DisplayNews.aspx?NewsID=22591\&LangID=E (accessed on 2 December 2019).

USCIS. 2019. Policy Manual, Chapter 11-Inadmissibility Determination. Available online: https://www.uscis. gov/policy-manual/volume-8-part-b-chapter-11 (accessed on 2 December 2019).

USCIS. n.d. Inadmissibility and Waivers. Available online: https://www.uscis.gov/sites/default/files/ USCIS/About\%20Us/Electronic\%20Reading\%20Room/Applicant\%20Service\%20Reference\%20Guide/ Inadmissibillity_and_Waivers.pdf (accessed on 2 December 2019).

Weil, Richard H. 1984. International adoptions: The quiet migration. International Migration Review 18: $276-93$. [CrossRef]

Welsh, Janet A., Andres G. Viana, Stephen A. Petrill, and Matthew D. Mathias. 2007. Interventions for internationally adopted children and families: A review of the literature. Child and Adolescent Social Work Journal 24: 285-311. [CrossRef]

World Bank. 2019. The World Bank in Honduras-Overview. Washington: World Bank, Available online: https://www.worldbank.org/en/country/honduras/overview (accessed on 2 December 2019).

(C) 2019 by the authors. Licensee MDPI, Basel, Switzerland. This article is an open access article distributed under the terms and conditions of the Creative Commons Attribution (CC BY) license (http://creativecommons.org/licenses/by/4.0/). 